\title{
Implementation of SPADA UWGM in Online Learning
}

Gamar Al Haddar ${ }^{1}$

DOI: 10.35445/alishlah.v13i1.392

Article Info

Keywords:

SPADA Application

Lecture

\section{Abstract}

This research was motivated by the obligation to conduct online lectures in the odd semester of 2020-2021 during the Covid-19 Pandemic. To prevent the transmission of the Covid-19 virus, associ ations involving large numbers of people are unallowed. Therefore, Widya Gama Mahakam University provides a SPADA application accessible by lecturers and students for a more convenient lecture. This study aimed to analyze the use of online applications in online learning. This research was qualitative. The data collection techniques used were interviews and documentation. Testing the validity of the data was carried out by triangulating the source. Based on the research results, at the planning stage, the SPADA UWGM application has provided a complete system for lecturers to make conceptual and systematic planning. At the implementation stage, the SPADA UWGM application helps lecturers to distribute recovery materials, conduct interactive discussions through forums. However, for faceto-face online, there are still obstacles, especially in networks difficult to stabilize. Hence, learning through online classrooms and conferences is less effective using this application. The SPADA UWGM application interestingly contributes to the evaluation stage, especially to easily fill questions through question banks, assessments, and feedback from lecturers to students.
Kata kunci:

Aplikasi

SPADA

Perkuliahan

\begin{abstract}
Abstrak
Penelitian ini dilatarbelakangi oleh adanya kewajiban untuk melaksanakan perkuliahan daring semester Ganjil 2020-2021 pada masa Pandemi Covid-19. Dalam rangka pencegahan penularan virus covid 19 maka tidak diperbolehkan adanya perkumpulan yang melibatkan banyak orang. Solusi yang diberikan oleh universitas Widya Gama Mahakam adalah menyediakan aplikasi SPADA yang dapat diakses oleh dosen dan mahasiswa untuk memberikan kemudahan dalam proses perkuliahan. Tujuan penelitian ini adalah menganalisis Penggunaan aplikasi daring dalam pembelajaran daring. Penelitian ini merupakan penelitian kualitatif. Teknik pengumpulan data yang digunakan yakni wawancara dan dokumentasi. Pengujian keabsahan data dengan triangulasi sumber. Berdasarkan hasil penelitian pada tahap perencanaan aplikasi SPADA UWGM telah menyediakan sistem yang lengkap bagi dosen untuk membuat perencanaan yang terkonsep dan sistematis. Pada tahap pelaksanaan aplikasi Spada UWGM memberikan kemudahan bagi dosen dalam melaksanakan dalam membagikan materi perkulihan, melakukan diskusi interaktif melalui forum, namun untuk tatap muka daring masih terdapat kendala khususnya di jaringan yang sulit stabil, sehingga
\end{abstract}

${ }^{1}$ Gamar Al Haddar, Universitas Widya Gama Mahakam, Samarinda, Indonesia

Email: gamar@uwgm.ac.id

Vol.13 (1) June, 2021

Received: February 16, 2021; Received in revised form: April 2, 2021; Accepted: April 4, 2021; Available online: May 11, 2021

This is an open access article under a Creative Commons Attribution-NonCommercial-ShareAlike 4.0 International License 
pembelajaran melalui classroom online dan conference kurang efektif dilaksanakan dengan aplikasi ini. Pada tahap evaluasi aplikasi SPADA UWGM memberikan konstribusi yang paling menarik terutama dalam mengarsipkan soal melalui bank soal, penilaian dan umpak balik dari dosen ke mahasiswa menjadi mudah untuk dilaksanakan

\section{INTRODUCTION}

During the Covid-19 pandemic, lectures were not conducted in a classroom but online. Lectures in high education have been held online starting in August 2020/2021 (SIARAN PERS Nomor: 137/sipres/A6/VI/2020, 2020). Learning is carried out online to avoid the spread of the covid-19 virus. $100 \%$ online learning is exciting and challenging for lecturers or educators. Educators are required to be skillful, creative, and independent during the Covid-19 pandemic. Although, in essence, every educator must be qualified, during the Covid-19 pandemic, they should be even more skilled in the learning process. (Novita \& Hutasuhut, 2020).

SPADA stands for Sistem Pembelajaran Daring (online learning system). The SPADA is one of the applications owned by the Ministry of Education and Culture, further developed by each educational unit. The reliability of the instruments used in SPADA has been tested as researched by Ayu and Rosli ( 2020), and the results showed that the reliability of each construct had a high value, viewed from the following factors, including infrastructure, students' independent learning, perceived benefits of the SPADA application, perceived ease of use, its users' attitudes and intentions of its.

SPADA has numerous benefits. This is proven by the results of research conducted by Dedi et al. (2020). Their study showed that the SPADA application could be the primary solution in online learning. Therefore, the standards used by educators in online learning activities are similar and can be measured by management. The impact is that online learning activities are easy to control properly. Widaya Gama Mahakam University officially launched the use of the SPADA UWGM application in June 2020. UWGM used this application in lectures on odd semester 2020/2021. UWGM Online Learning System (SPADA) can be used anywhere and anytime. Access to course content can be undertaken on a laptop, cellphone, tablet, or desktop. SPADA has a complete section in the lecture.

In online lectures, the stages are planning, implementing, and evaluating. The planning stage is carried out from the beginning after the teaching certificate is given. The planning stage is an essential part of online learning preparation. The next stage is implementation. This stage will run smoothly if it is supported by thorough planning. The last stage is evaluation. Evaluation is to measure teaching success. This stage is the most significant part since, at this stage, we will know the quality of our teaching (Muryadi, 2017)

Based on the background mentioned above, the researcher was interested in further analyzing the use of the SPADA UWGM application in online lectures for the odd semester of 2020-2021.

\section{METHODS}

According to Sugiono (2018), qualitative research is applied to examine a natural object. In this case, the researcher is the key instrument. The data analysis is inductive, and the results of qualitative research emphasize the meaning in the form of descriptive or words without numbers. Qualitative research (Ahmadi, 2014) aims to understand the phenomenon occurring scientifically in the happening situation. This concept emphasizes the importance of the data obtained by qualitative research. That is, scientific data are mainly attained from research subjects. The data gained in qualitative research are what resource persons do. They are submitted by a set of statements by the researcher.

This research was conducted at Widya Gama Mahakam University, a private university located on Wahid Hasyim I Street, Samarinda. The study was carried out in the odd semester of 
2020-2021, namely August to December 2020. The subjects of this research were five lecturers and ten students of the PGSD FKIP UWGM study program.

Data collection techniques used were semi-structured interviews and documentation. The data obtained in the field were then analyzed. Data analysis in this study was performed through four stages, namely data collection, data reduction, data presentation, and concluding. The collected data will be selected and presented in accordance with the research objectives To make this research scientifically accountable, it carried out a data validity test employing triangulation. According to Moleong (2014), triangulation is a data checking technique using something outside the data for checking purposes or as a comparison against that data. The type of triangulation used in this research was source triangulation. Triangulation of sources, namely looking for the validity of the data by comparing the results of interviews from several different sources. the goal is to get valid and reliable data

\section{FINDINGS AND DISCUSSION}

In this study, the researcher describes the analysis of the SPADA UWGM application in three parts, namely planning, implementation, and evaluation. The SPADA UWGM is accessible via a link www.spada.uwgm.ac.id

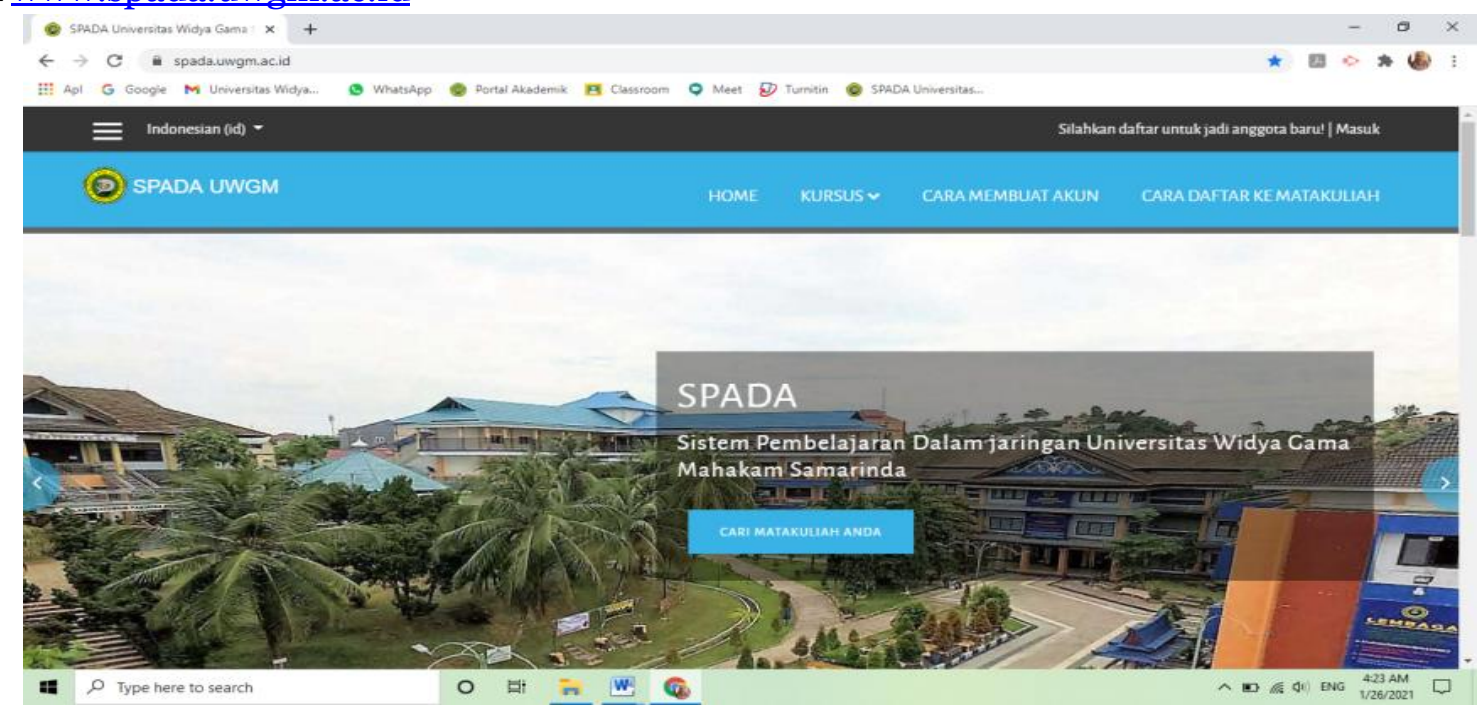

Figure 1. Display of SPADA UWGM

The results of interviews and documentary studies regarding three indicators are explained as follows.

\section{Lecture Planning Using SPADA UWGM Application}

The initial stage carried out before conducting lecture activities was making plans. The planning was created by the lecturer based on the Semester Lesson Plan that had been prepared. By turning on the change mode in the SPADA application, the lecturer can arrange various activities to be added and performed in lecture activities. Planning in online learning is conducted as in face-toface lectures (Kuntarto, 2017). The lecturers prepared the Semester Lesson Plan and assignments and determined methods, learning media, and others. The various preparations were adjusted to the learning techniques carried out, namely online. 


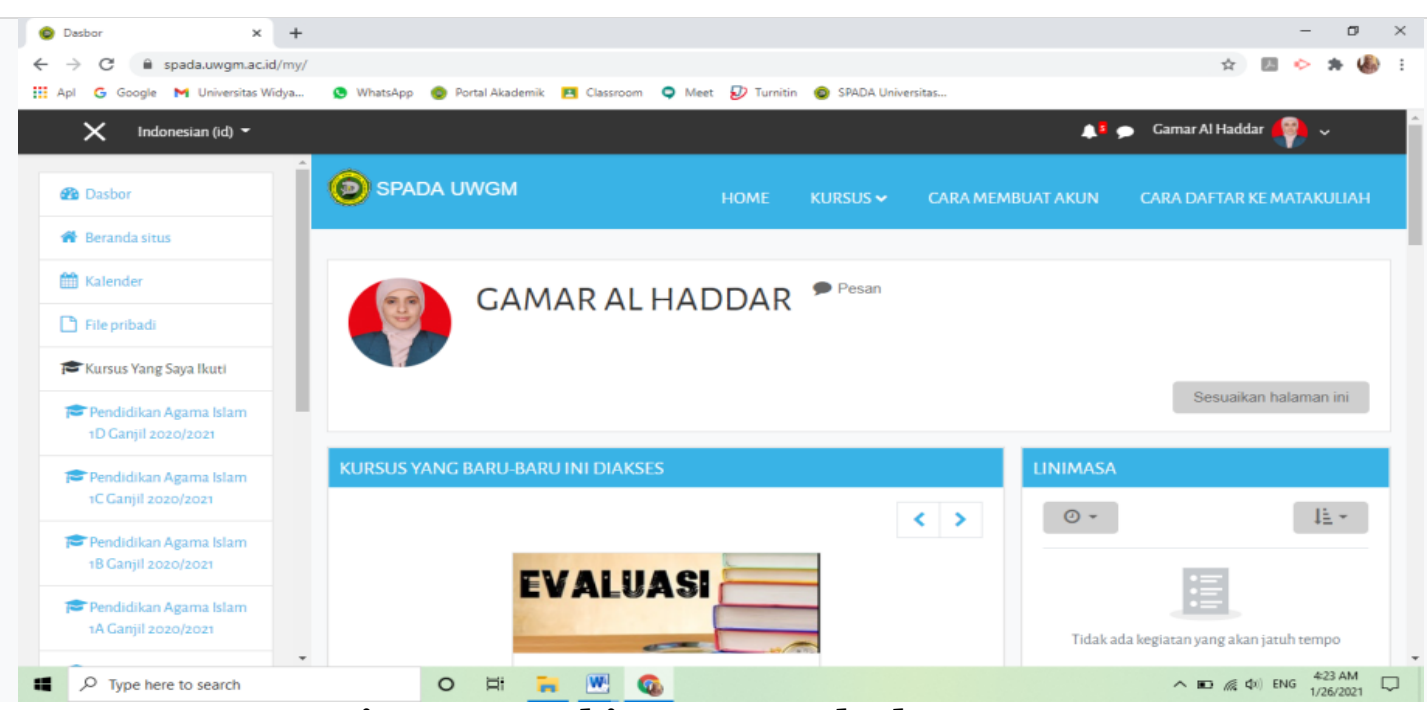

Figure 2. Making courses by lectures at SPADA

Research conducted by Kurniawan, B., \& Purnomo ( 2020) mentioned that the planning stage could improve teachers' skills. Educators became more skilled and independent in preparing their lesson plans by provisioning and training, as has been done by the faculties at Widya Gama Mahakam University, Samarinda. Provision and training were provided for lecturers before implementing the SPADA system in actual lectures.

The first plan executed by the lecturer was making lecture attendance. Attendance was made according to the lecture schedule set by the study program. Lecturers set hours and time limits for students to do absences. If it was outside the specified hours, students were unallowed to attend the online class. The second plan before lectures started was the lecturer created meetings using an online classroom or conference. The third plan was the lecturers could upload materials they wanted to share with students through material/module/file activities by clouding the file to the system. A URL facility is available if the material shared has a link.

Based on the interview results, learning planning with the SPADA application was easy, practical, and economical. However, some obstacles occurred, namely network stability and internet data. The SPADA application helps to organize and make plans before holding lectures. This application facilitates lecturers to make conceptual and neat plans as well.

\section{Conducting Lectures Using SPADA UWGM Application}

Lectures in the odd semester of 2020-2021 started from September to December 2020. The courses were held online. Lecture activities run smoothly even though several obstacles were faced in the implementation of online lectures using the SPADA system.

Students could do the absence directly according to the time limit determined. Lecturers could socialize through chat forums in the SPADA application. Attendance lists through SPADA caused students disciplined in attending lectures. The system is strict. For example, if the time runs out, the attendance will be closed and there will be no opportunity for students to check the attendance list. Suppose students are unable to attend the online class due to sickness or other activities requiring permission for them to absent in the learning. In that case, they can write their reason down directly on the SPADA application. As has been researched by Syarifudin (2020), online learning made students independent and focused on education. Filling in the attendance list promptly also indicated the students' independence. 


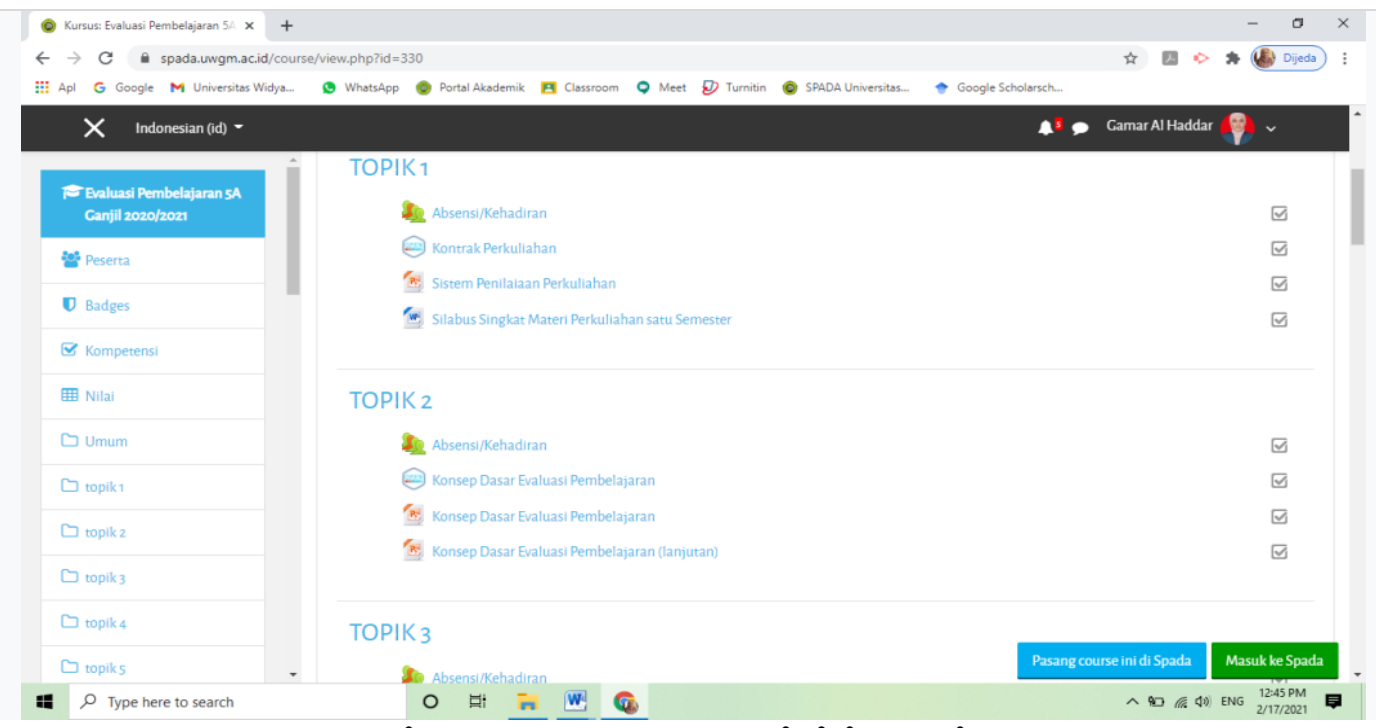

Figure 3. Lecture activities using SPADA

Based on the interview results, online classrooms and conferencing had several obstacles, namely unstable networks causing it challenging to display videos of participants or students taking classes, even sometimes the networks broke up. This problem occurred when the learning took place. Therefore, to do face-to-face learning, students did not turn on the video. Then, the lectures could run smoothly, but the lecturer teaching could not fully control their students because their videos were disabled. One of the efforts made by the lecturer to overcome such a problem was using other applications for face-to-face, such as using zoom. However, for attendance activities, assignments, materials, and others, they still used the SPADA application. Interactive discussions with students could still be carried out through chat forums and the zoom application. One of the ideal learning requirements is being interactive, as in the research of Oktavian \& Aldya (2020), mentioning that an essential component in learning activities is interactive. This means that in online lectures, interactive discussions are also needed. The goal is to make the learning meaningful and fun. The SPADA application helps the implementation of effective and efficient learning. As explained in Pangondian et al. (2019) research, effectiveness was the most primary thing in online learning.

One of the advantages of the SPADA application is providing learning resources for students. This learning resource is a place for students to download the material that the lecturer has distributed. Students can download at any time. The material/module contains supporting files, for example, presentation files in the form of powerpoints, PDF, Microsoft Word, and others. If the lecturer has a learning youtube link, the link can be shared and watched directly by students.

In its implementation, in general, there are still obstacles, but these constraints are not related to the SPADA application but users. Namely, the signal strength in each region of the students and lecturers in each region could be different. For lecturers and students with bad signals, it is difficult to access and continue their learning. As research that has been done by (Yuliana, 2020), the signal strength and data were the obstacles in online learning.

\section{Lecture Evaluation Using SPADA UWGM Application}

Evaluation is the most significant part of teaching and learning activities. Without an evaluation, the lecturer cannot identify the students' achievements reached from the learning process (Gamar, 2019). Lecturers can carry out continuous evaluation in online learning. The SPADA application provides quiz and task activities.

Quiz is the most engaging and fun learning activity. In this activity, the lecturer can create various questions, including multiple-choice, description, short and numerical answers questions. Lecturers can allow students to take exams or answer questions several times, with questions randomized by the question bank. Time limits may have been set. Every time you take an exam or 
answer a question, you will be marked or graded automatically, except for essay or description questions, and the score will be recorded in the grade book. Lecturers can determine the time for the exam or according to a predetermined schedule. The feedback and correct answers can be shown to students. With this quiz, lecturers can find out the students' competence directly and quickly at each meeting according to the planning made by the lecturer.

The evaluation of the implementation of the middle-examination and final-examination can utilize this quiz as well. Questions made by the lecturer at the previous meetings can be entered into the question bank. Lecturers can also add and make new questions according to the material. Then, they set the time based on the planned schedule. Questions can be randomized so that there is no possibility of scattering questions among students and other problems occurring.

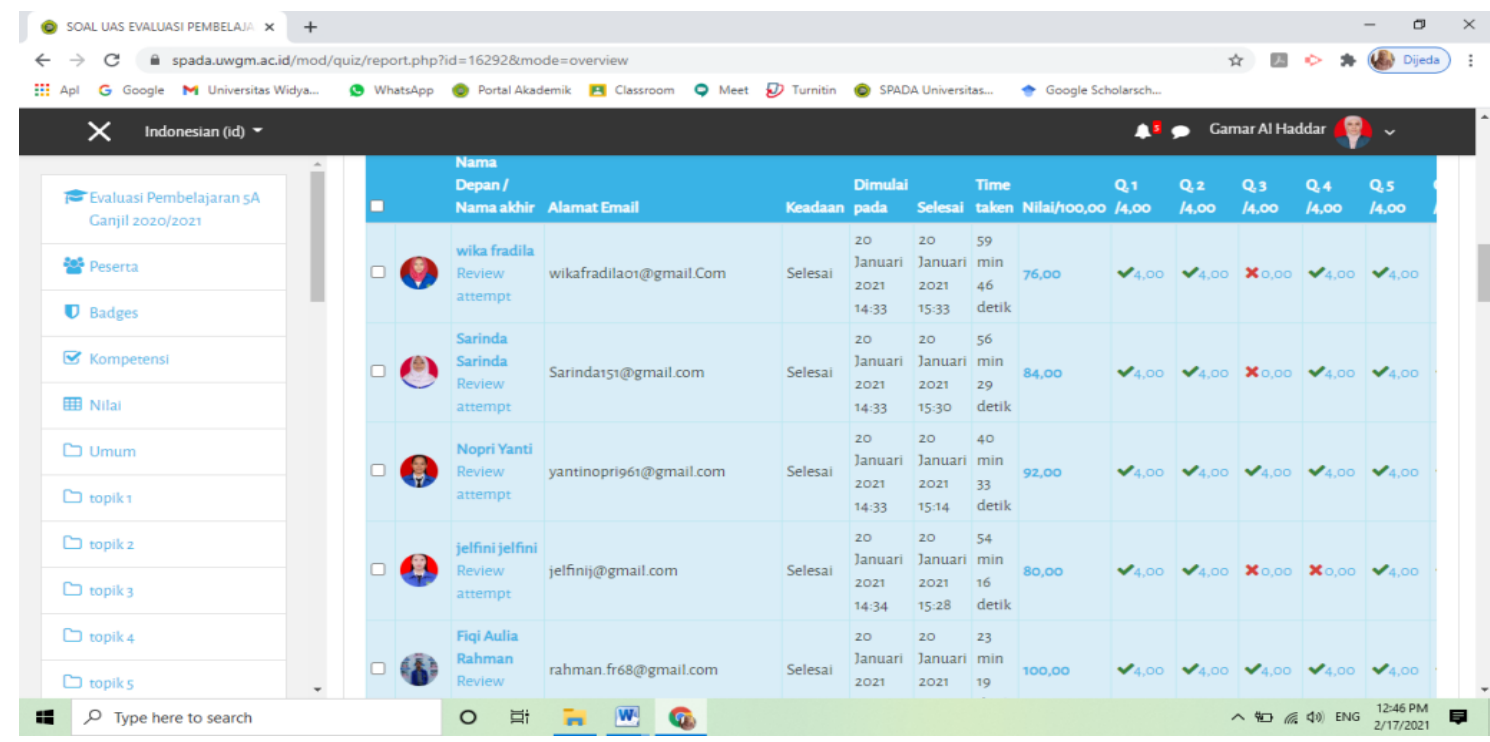

Figure 5. Display of final-exam results from SPADA system

By using quizzes for exercises at every meeting, mid-term, and final exam, lecturers can identify their students' competence and measure their success in teaching since the purpose of the evaluation is to measure the success of teaching.

In addition to quizzes, lecturers can also use assignment activities in evaluation. Assignments are given to students based on the planned topic. The Assignment Module helps lecturers to provide, collect, and make assessments as well as feedback. Students can send any digital form (file), such as Microsoft Word, Microsoft Excel, images, audio, and video files. Or, besides, Assignments ask students to type text directly into the editor. Assignments can be used to alert students to assignments they must complete similarly to offline learning. Students can submit assignments individually or in groups. When checking assignments, lecturers can provide comments and feedback (Ayu \& Rosli, 2020) and upload files, such as student submissions that have been scored, documents with comments, or spoken audio feedback. The assignments can be assessed with a numerical scale or a special scale. The final grade is written in the assessment book.

SPADA application also provides excellent benefits, especially for UWGM, in controlling and evaluating the lecturers' performance teaching and learning process. This is as has been researched by Darwis, D., Saputra \& Ahdan (2020), stating that SPADA facilitated management to monitor and evaluate lecturers' performance results.

\section{CONCLUSION}

The results of research on the use of the SPADA UWGM application in online lectures in the odd semester of 2020-2021 showed that the SPADA UWGM application has had provided a complete system for lecturers at the planning stage to make conceptual and systematic planning. At the implementation stage, the SPADA UWGM application helps lecturers to easily distribute recovery 
materials and conduct interactive discussions through forums. However, for face-to-face online, there are still obstacles, especially unstable networks, so learning through online classrooms and conferences is less effective using this application. At the evaluation stage, the SPADA application provides the most interesting contribution, especially in filing questions through question banks. Giving assessments and feedback from lecturers to students is easy to implement.

\section{REFERENCES}

Ahmadi, R. (2014). Metodologi Penelitian Kualitatif. Ar-Ruzz Media.

Ayu, S., \& Rosli, M. S. B. (2020). Uji Reliabilitas Instrumen Penggunaan SPADA (Sistem Pembelajaran dalam Jaringan). Biormatika: Jurnal Ilmiah Fakultas Keguruan Dan Ilmu Pendidikan, 6(1), 145-155.

Darwis, D., Saputra, V. H., \& Ahdan, S. (2020). Peran Sistem Pembelajaran Dalam Jaringan (SPADA) Sebagai Solusi Pembelajaran pada Masa Pendemi Covid-19 di SMK YPI Tanjung Bintang. Prosiding Seminar Nasional Darmajaya, Vol. 1, 36-45.

Gamar, A. H. (2019). Evaluasi Pembelajaran. Kaafah Learning Center.

Kuntarto, E. (2017). Keefektifan model pembelajaran daring dalam perkuliahan bahasa Indonesia di perguruan tinggi. Indonesian Language Education and Literature, 3(1), 99-110.

Kurniawan, B., \& Purnomo, A. (2020). Penggunaan Aplikasi Google Classroom Sebagai Upaya Peningkatan Pembelajaran Online Bagi Guru Matapelajaran IPS. International Journal of Community Service Learning, 4(1), 1-9.

Moleong, L. J. (2014). METODOLOGI PENELITIAN KUALITATIF. ROSDA.

Muryadi, A. D. (2017). Model evaluasi program dalam penelitian evaluasi. Jurnal Ilmiah Penjas (Penelitian, Pendidikan Dan Pengajaran), 3 (1).

Novita, D., \& Hutasuhut, A. R. (2020). Plus Minus Penggunaan Aplikasi Aplikasi Pembelajaran Daring Selama Pandemi Covid 19. Unimed.

Oktavian, R., \& Aldya, R. F. (2020). Efektivitas Pembelajaran Daring Terintegrasi di Era Pendidikan 4.o. Didaktis: Jurnal Pendidikan Dan Ilmu Pengetahuan, 20 (2).

Pangondian, R. A., Santosa, P. I., \& Nugroho, E. (2019). Faktor-faktor yang mempengaruhi kesuksesan pembelajaran daring dalam revolusi industri 4.o. Seminar Nasional Teknologi Komputer \& Sains (SAINTEKS), 1 (1).

Saputro, B., \& Susilowati, A. T. (2019). Effectiveness of Learning Management System (LMS) on In-Network Learning System (SPADA) Based on Scientific. Journal for the Education of Gifted Young Scientists, 7(3), 481-498.

SIARAN PERS Nomor: 137/sipres/A6/VI/2020. (2020). Kementerian Pendidikan dan Kebudayaan. https://www.kemdikbud.go.id/main/blog/2020/o6/panduanpenyelenggaraan-pembelajaran-pada-tahun-ajaran-dan-tahun-akademik-baru-di-masacovid19

Sugiono. (2018). METODE PENELITIAN Kualitatif, Kuantitatif, dan R\&D. Alfabeta.

Syarifudin, A. S. (2020). Impelementasi pembelajaran daring untuk meningkatkan mutu pendidikan sebagai dampak diterapkannya social distancing. Jurnal Pendidikan Bahasa Dan Sastra Indonesia Metalingua, 5(1), 31-34.

Yuliana, W. (2020). Efektifitas Pembelajaran Daring Di Tengah Wabah Pandemi Covid-19 Di Universirtas Abdurachman Saleh Situbondo. Jurnal IKA PGSD (Ikatan Alumni PGSD) UNARS, 8(2), 417-428. 